\title{
IMPLEMENTASI GAYA KEPEMIMPINAN YESUS SEBAGAI ROLE-MODEL DALAM KEHIDUPAN PEMURIDAN
}

\author{
Christopher Alexander ${ }^{1^{*}}$, Jonathan Aristo ${ }^{2}$, \\ Bait Adetya Situmorang ${ }^{3}$, Tony Tedjo ${ }^{4}$ \\ 1,2,3,4 Sekolah Tinggi Teologi Kharisma Bandung \\ Email: calexander.ca26@gmail.com

\section{IMPLEMENTATION OF JESUS' LEADERSHIP STYLE AS} \\ ROLE-MODELS IN THE LIFE OF DISCIPLES
}

\begin{abstract}
Leadership is an inevitable thing in life on this occasion, the author raised the topic "Implementation of Jesus' Leadership Style as a Role-Model in the Life of Discipleship", to remind the church today so that the church can produce qualified disciples according The method used in this research is the library research approach, in which the authors take various arguments from the existing literature. The conclusion in this study is that a disciple must have four aspects that reflect on what Jesus did during His ministry on this earth: (1) The basic principles of discipleship, namely being Christ-centered, introducing God as Father, and leading with compassionate heart; (2) Responsibilities of making disciple, namely delegating tasks and evaluating students; (3) How a disciple must behave, namely serving with a servant's heart, being an example in all things, and being a shepherd who cares for his sheep; and also (4) Discipleship patterns, namely acceptance, companionship, and commissioning.
\end{abstract}

Keywords: leadership style, Jesus' leadership, servant leadership, discipleship

Abstrak: Kepemimpinan adalah hal yang tidak terelakkan lagi dalam kehidupan Itu sebabnya, gereja perlu membekali para pemurid sebagai orang yang akan memimpin orang lain, agar mereka dapat memuridkan dengan baik, salah satunya dengan bekal aspek kognitif.Metode yang digunakan dalam penelitian ini adalah dengan pendekatan studi pustaka, di mana penulis mengambil berbagai argumen dari literaturliteratur yang ada. Yang menjadi kesimpulan dalam penelitian ini adalah seorang pemurid haruslah memiliki empat aspek yang berkaca pada apa yang Yesus lakukan semasa pelayanan-Nya di muka bumi ini: (1) Prinsip dasar memuridkan, yaitu berpusatkan pada Kristus, memperkenalkan Allah sebagai Bapa, dan memimpin dengan hati yang berbelas kasih. (2) Tanggung jawab pemurid, yaitu mendelegasikan tugas serta mengevaluasi murid. (3) Bagaimana seorang pemurid harus bersikap, yaitu melayani dengan hati hamba, menjadi teladan dalam segala hal, dan menjadi gembala yang peduli dengan dombadombanya. (4) Pola pemuridan, yaitu penerimaan, penemanan dan pengutusan.

Kata kunci: gaya kepemimpinan, kepemimpinan Yesus, kepemimpinan hamba, pemuridan

\section{PENDAHULUAN}

Dewasa ini, buku-buku yang di dalamnya memuat materi-materi yang berkenaan dengan kepemimpinan (leadership) dan program-program pelatihan yang dibuat untuk mengembangkannya sangat laris diminati oleh berbagai kalangan, baik dalam bidang bisnis, politik, sipil, maupun organisasi sosial lainnya. Topik mengenai yang dilakukan oleh Yesus, Sang Role-Model, yang menjadi panutan/teladan bagi gereja. kepemimpinan ini juga dijadikan sebagai subjek kajian dalam berbagai disiplin ilmu, misalnya antara lain: psikologi, sosiologi, politik, manajemen, dan juga teologi. Alhasil, bermacam-macam konsep kepemimpinan bermunculan, dan hal itu 
tentunya sangat bervariasi. ${ }^{1}$

\section{Konsep kepemimpinan Kristiani} juga sangat berbeda dengan konsep kepemimpinan dunia. Pemimpin Kristen diharuskan untuk dapat memainkan perannya dengan baik dan maksimal, karena kepemimpinan seorang pemimpin Kristen sangatlah berpengaruh terhadap perkembangan serta pertumbuhan gereja ataupun komunitas Kristen tempat di mana ia memimpin, yang kemudian juga akan berkaitan dengan pertumbuhan kualitas maupun kuantitas para anggota/bawahan/jemaatnya. ${ }^{2}$

Berfokuskan pada pentingnya kepemimpinan dalam sebuah gereja, maka sebenarnya gereja memiliki tanggung jawab mutlak untuk melahirkan dan mempersiapkan pemimpin-pemimpin di masa yang akan datang demi terciptanya pemimpin-pemimpin Kristen yang berkualitas. $^{3}$

Salah satu yang menjadi bukti bahwa kepemimpinan sangatlah penting dalam kehidupan bergereja adalah karena kepemimpinan juga diperlukan dalam kehidupan pemuridan. Hartono, seperti yang dikutip oleh Darmawan, mengatakan bahwa inti dari amanat agung sebenarnya adalah pemuridan, di mana di dalamnya tercakup tugas penginjilan dan pengajaran dalam rangka memperlengkapi setiap murid-murid Kristus untuk melakukan pelayanan. ${ }^{4}$ Lebih lanjut lagi, Darmawan mengatakan bahwa implementasi dari amanat agung dalam

${ }^{1}$ Yahya Wijaya, "Kepemimpinan Yesus sebagai Acuan bagi Kepemimpinan Gereja Masa Kini," Jurnal Jaffray 16, no. 2 (Juli 24, 2018): 129.

${ }^{2} \mathrm{~K}$. Katarina dan Krido Siswanto, "Keteladanan Kepemimpinan Yesus dan Implikasinya bagi Kepemimpinan Gereja Pada Masa Kini," Jurnal Evangelikal 2, no. 2 (Juli 31, 2018): 87.
Matius 28:18-20 haruslah dikerjakan oleh gereja secara efektif dalam tugas pemuridan. Di mana pemuridan merupakan suatu bagian dari pelayanan gereja yang tidak dapat dipisahkan, sebab keduanya merupakan satu kesatuan. $^{5}$

Berkaitan dengan kepemimpinan dalam sebuah pemuridan, kepemimpinan tersebut dimanifestasikan dalam pemuridan di saat seorang pemurid (mentor/bapa rohani) sedang memuridkan muridnya (mentee/anak rohani). Seorang pemurid haruslah dapat memimpin muridnya, dan pada fase inilah kepemimpinan mengambil peran dalam sebuah pemuridan.

Dengan demikian, kepemimpinan sangatlah perlu menjadi sebuah concern bagi setiap gereja, agar tongkat estafet tersebut tidaklah putus, melainkan tetap berkelanjutan. Seperti halnya yang dilakukan oleh Musa, di mana ia mempersiapkan (memuridkan) Yosua agar kelak Yosua dapat memimpin bangsa Israel masuk ke dalam tanah Perjanjian untuk melanjutkan tongkat estafet kepemimpinan Musa. Hal ini jugalah yang seharusnya dilakukan oleh setiap gereja, yaitu mempersiapkan pemimpin-pemimpin yang berkualitas di masa mendatang agar tongkat estafet kepemimpinan tidaklah berhenti sampai di saat itu saja, melainkan gereja dapat melanjutkan eksistensi dan perjuangannya di tengah-tengah dunia yang semakin jahat ini melalui kehidupan pemuridan, sambil menanti kedatangan Sang

${ }^{3}$ Santy Sahartian and Samuel Brian Septiadi, "Tugas Pemimpinan Muda Kristen Masa Kini Sebagai Gembala enurut 1 Timotius 4," Angelion 1, no. 1 (2020): 84.

${ }^{4}$ I Putu Ayub Darmawan, "Jadikanlah Murid: Tugas Pemuridan Gereja menurut Matius 28:18-20," Jurnal Evangelikal 3, no. 2 (Juli 31, 2019): 145.

${ }^{5}$ lbid. 
Mempelai Pria dengan menuntaskan perjuangan tugas dan panggilan gereja di muka bumi ini.

Lalu, yang menjadi pertanyaan adalah bagaimana seorang pemurid atau mentor dapat dikatakan 'berkualitas' dan mampu memuridkan dengan baik? Maka dari itu, penulis merasa perlu untuk mengangkat topik "Implementasi Gaya Kepemimpinan Yesus sebagai Role-Model Dalam Kehidupan Pemuridan", untuk mengingatkan gereja masa kini agar gerejagereja dapat mempersiapkan para pemimpin-pemimpin yang berkualitas demi terlahirnya para pemurid-pemurid (mentormentor) yang dapat melaksanakan misi Amanat Agung Tuhan Yesus, dengan cara mengimplementasikan gaya kepemimpinan

\section{METODE}

Metode pendekatan yang digunakan

\section{PEMBAHASAN}

\section{Kepemimpinan Yesus}

Kepemimpinan adalah salah satu faktor yang tidak pernah diabaikan dalam sebuah organisasi atau institusi. Pembahasan mengenai kepemimpinan pun tidak pernah menjadi sunyi dan kadaluarsa. Menurut Mawikere, hal tersebut dapat terjadi karena, pemimpin adalah berbicara mengenai agen perubahan (Leaders are the Currency of change). ${ }^{7}$ Arthanto juga menambahkan pendapatnya, bahwa keberadaan dari kepemimpinan tidaklah dapat disangkal, sebab kepemimpinan

\footnotetext{
${ }^{6}$ Milya Sari dan Asmendri, "Penelitian Kepustakaan (Library Research) dalam Penelitian Pendidikan IPA," Natural Science: Jurnal Penelitian Bidang IPA dan Pendidikan IPA 6, no. 1 (2020): 41-53.

${ }^{7}$ Marde Christian Stenly Mawikere, "Efektivitas, Efisiensi dan Kesehatan Hubungan Organisasi Pelayanan dalam Kepemimpinan
}

dalam penelitian ini berupa pendekatan studi pustaka (library research), di mana pengumpulan data dilakukan dengan menelaah berbagai buku, literatur, catatan, serta laporan yang berkenaan dengan pokok permasalahan yang ingin dipecahkan. ${ }^{6}$ Dalam hal ini, dari permasalahan yang ada, penulis memaparkan kedua variabel dalam judul penelitian ini secara terperinci satu per satu, didukung dengan argumen-argumen dari para ahli di bidangnya. Kemudian, penulis berusaha untuk memperlihatkan keterkaitan antara variabel yang satu dengan variabel yang lain untuk mendapatkan suatu kesimpulan yang praktikal dan komprehensif. Dalam menunjang penelitian ini, penulis menyertakan dukungan argumentasi dari berbagai ahli dari sumber primer yang tersedia secara online yang dapat diakses dengan leluasa, yaitu jurnaljurnal yang tersedia dalam bentuk online. merupakan salah satu faktor yang secara signifikan dan berkelanjutan berkaitan dengan keberhasilan suatu organisasi atau institusi dalam mencapai tujuannya tersebut. ${ }^{8}$

\section{Definisi Kepemimpinan}

Adapun definisi kepemimpinan yang dikemukakan oleh Walter yang dikutip oleh Lase, yaitu kepemimpinan adalah suatu usaha seseorang untuk dapat memberi pengaruh kepada pikiran, kebiasaan, keyakinan atau nilai-nilai dari pribadi lain. ${ }^{9}$ Robert dan Clinton juga memiliki definisi yang serupa mengenai kepemimpinan, mereka berkata bahwa kepemimpinan

Kristen," Jurnal Evangelikal 2, no. 1 (Februari 23, 2018), accessed May 22, 2021, https://journal.sttsimpson.ac.id/index.php/EJTI/a rticle/view/95.

8 lbid., 95.

9 Jason Lase, "Kepemimpinan dan Tantangan Pluralisme Sosial," Jurnal Jaffray 7 , no. 1 (2009): 1-15. 
merupakan suatu proses yang direncanakan sebelumnya dan bersifat dinamis, melalui suatu masa waktu dalam kondisi yang ada di dalamnya seorang pemimpin menggunakan setiap sarana dan sumber daya yang ia miliki untuk menggerakan bawahannya agar dapat melaksanakan setiap tugas dan tanggung jawabnya dalam rangka mencapai tujuan dan mencapai keuntungan yang dapat dirasakan oleh pemimpin, bawahan dan serta lingkungan di mana mereka berada. ${ }^{10}$ Menurut Josua syarat terpenting dan terutama untuk dapat menjadi seorang pemimpin adalah kemampuan untuk dapat mempengaruhi orang yang dipimpinnya tersebut. ${ }^{11}$

Melalui definisi-definisi mengenai kepemimpinan di atas, kita dapat menyimpulkan bahwa kepemimpinan adalah berbicara tentang bagaimana seorang pemimpin dapat memberi pengaruh terhadap orang-orang yang dipimpinnya. Oleh sebab itu, seorang pemimpin dituntut untuk dapat memiliki pengaruh (dampak) terhadap orang yang dipimpinnya tersebut, bahkan terhadap khalayak ramai di sekitar lingkungannya.

\section{Kepemimpinan Kristen}

Kepemimpinan sendiri juga bersangkutan dengan iman/kepercayaan seseorang, oleh sebab itu, ada juga yang disebut dengan kepemimpinan Kristen. Tenny dan Areyne mengutip definisi kepemimpinan dari Sander, ia berkata

\footnotetext{
${ }^{10}$ Mawikere, "Efektivitas, Efisiensi dan Kesehatan Hubungan Organisasi Pelayanan dalam Kepemimpinan Kristen", 51.

${ }^{11}$ Josua Marsorin Simanjuntak, "Pentingnya Memahami Kepemimpinan menurut Lukas 22:26," Jurnal Stella 1, no. 1 (2021): 2944,60 .

${ }^{12}$ Tenny Sudibyo dan Areyne Christi, “Implementasi Prinsip Kepemimpinan Paulus
}

bahwa kepemimpinan Kristen dapat disebut juga dengan kepemimpinan rohani. Perbedaan di antara dua macam kepemimpinan ini adalah dapat dilihat dari kualifikasi dan kemampuan atau cara dari seorang pemimpin Kristen dalam mempengaruhi bawahannya atau orangorang yang dipimpinnya, kesanggupan dan kemampuan dalam mempengaruhi orang yang dipimpinnya pun juga bukan berdasarkan dari kekuatan diri sendiri, melainkan berasal dari Roh Kudus yang di mana seorang pemimpin Kristen ini diterangi dan dimampukan oleh Roh Kudus untuk memimpin. ${ }^{12}$ Jadi, kepemimpinan Kristen sangat erat dengan pribadi ketiga dari Allah Tritunggal, yaitu Roh Kudus. Pada dasarnya, tidak hanya Roh Kudus saja, tetapi kepemimpinan Kristen juga harus didasarkan pada Alkitab. Ginting et.al menjelaskan bahwa kepemimpinan Kristen haruslah mempunyai dasar Theosentris (berpusatkan kepada Tuhan). ${ }^{13}$ Seorang pemimpin Kristen mempunyai tugas yang pasti, yaitu memimpin setiap orang yang berada di bawah kepemimpinannya, bukan hanya sekadar menjalankan tugas dan tanggung jawabnya sebagai masyarakat sosial, melainkan terlebih lagi juga untuk menjalankan tugas dan panggilannya sesuai dengan firman Tuhan. Menurut Purnama di dalam bukunya, ia berkata bahwa seorang pemimpin Kristen seharusnya membina setiap orang yang dipimpinnya tersebut agar mereka di dalam prakteknya dapat

berdasarkan Surat 1 Timotius 3:1-13 \& 2 Timotius 2:2-6 di Kalangan Civitas Akademika Sekolah Tinggi Teologi", Jurnal Excelsior Pendidikan 1, no. 1 (2020): 24.

${ }^{13}$ Yudhy Sanjaya, Kepemimpinan Kristen: Leader sebagai Kualifikasi Kepemimpinan Nehemia, preprint (Open Science Framework, August 4, 2020), accessed May 29, 2021, https://osf.io/vchns.72

48 | Jurnal Excelsis Deo: Jurnal Teologi, Misiologi dan Pendidikan 
menyanggupi setiap tugas dan tanggung jawab yang diberikan. ${ }^{14}$ Simanjuntak mengatakan bahwa kepemimpinan berbicara tentang bagaimana seorang pemimpin dapat mengartikulasikan visi, mewujudkan nilai serta menciptakan lingkungan untuk mencapai suatu tujuan, di mana pemimpin Kristen melakukan kepemimpinannya atas dasar kasih yang ditujukan untuk melayani Kristus. ${ }^{15}$

Menurut Sendjaya, seperti yang dikutip oleh Simanjuntak, kepemimpinan yang sehat dan efektif berbicara tentang kepemimpinan yang alkitabiah/biblikal. ${ }^{16}$ Dengan demikian, sudah seharusnya bagi para pemimpin untuk melihat ke dalam Alkitab mengenai bagaimana Yesus melakukan kepemimpinannya.

\section{Gaya Kepemimpinan Yesus}

Octavianus (1998), seperti yang dikutip oleh Irawati, menuliskan bahwa meneladani Yesus Kristus adalah sama artinya dengan memanifestasikan kehadiran-Nya di muka bumi ini, dengan sambil memenuhi tujuan untuk memperbaharui hidup serta memberikan hidup yang kekal kepada umat manusia yang percaya kepada-Nya. ${ }^{17}$ Yesus menjadi satu-satunya teladan (role-model) yang sempurna bagi setiap umat Kristen. Maka dari itu, kepemimpinan seorang Kristen pun haruslah berorientasikan kepada

${ }^{14}$ Purnama Pasande, "Pemimpin dan Kepemimpinan Kristen (Memahami Substansi Kepemimpinan Kristen)", OSF Preprints (2020), 68.

${ }^{15}$ Hotman Parulian Simanjuntak, "Implementasi Kepemimpinan Yesus Kristus menurut Yohanes 13:1-20," Jurnal Shamayim 1, no.1 (2020): 62.

${ }^{16}$ lbid., 60.

${ }^{17}$ Enny Irawati, "Keteladanan Kepemimpinan Yesus serta Implikasi terhadap kepemimpinan Yesus. Menurut Wijaya, gaya kepemimpinan Yesus adalah gaya kepemimpinan pelayan/hamba (servant leadership). ${ }^{18}$ Tetapi yang menjadi pertanyaan mendasar adalah apakah seorang pemimpin yang mempunyai kedudukan dan tempat yang tinggi dapat memimpin dengan melayani seperti seorang hamba? Terdapat dua jawaban atas pertanyaan ini, yaitu pertama, melalui sabda Yesus, "sama seperti Anak Manusia datang bukan untuk dilayani, melainkan untuk melayani dan untuk memberikan nyawa-Nya menjadi tebusan bagi banyak orang." (Matius 20:28). Dalam sabda Yesus ini dinyatakan secara eksplisit bahwa seorang pemimpin Kristen dapat memimpin dengan melayani, karena seperti yang dikutip oleh Tomatala dari Eka, yaitu Yesus sendiri yang telah mengajarkan, Ia juga yang mempraktekkannya secara konsisten. ${ }^{19}$ Kedua, kita akan mendapatkan jawaban melalui peristiwa Perjamuan Malam, di mana pada saat itu Yesus membasuh kaki murid-murid-Nya, sekalipun pekerjaan tersebut lazimnya dilakukan oleh para budak. ${ }^{20}$ Sikap rendah hati dan menghamba seperti yang dipertunjukkan oleh Yesus inilah yang seharusnya menjadi patokan bagi umat Kristen untuk memimpin, karena sikap rendah hati tersebut akan mempunyai pengaruh yang sangat besar bagi perubahan hidup orang-orang yang

Kepemimpinan Gereja pada Masa Kini," Jurnal IImu Sosial dan Humaniora 10, no.1 (2021): 171.

${ }^{18}$ Yahya Wijaya, "Kepemimpinan Yesus sebagai Acuan bagi Kepemimpinan Gereja Masa Kini", 136.

19 Yakob T. Tomatala, "Leading by Serving: Memimpin Dengan Melayani," Voice of Wesley 2, no. 2 (2019): 3.

${ }^{20}$ Yahya Wijaya, "Kepemimpinan Yesus sebagai Acuan bagi Kepemimpinan Gereja Masa Kini”, 136. 
dipimpin. $^{21}$ Simanjuntak juga memiliki pendapat yang sama mengenai gaya kepemimpinan Yesus yang adalah kepemimpinan hamba. Menurutnya, memimpin berbicara juga tentang menghamba dan seorang pemimpin Kristen harus memiliki motivasi seorang hamba yang mau melayani. ${ }^{22}$ Jadi, setiap pemimpin Kristen seyogyanya memiliki sikap rendah hati dan memiliki kepemimpinan menghamba sama seperti Kristus.

Menurut Wijaya, ada beberapa aspek dalam gaya kepemimpinan hamba yang Yesus lakukan, yaitu diantaranya: (1) Kerajaan Allah menjadi acuan dasar kepemimpinannya; (2) memperkenalkan Allah sebagai Bapa; dan (3) memimpin atas dasar hati yang tergerak oleh belas kasihan. ${ }^{23}$ Menurut Simanjuntak, terdapat hal yang kontradiktif antara kepemimpinan manusia dengan kepemimpinan Yesus, di mana kepemimpinan yang Yesus lakukan adalah kepemimpinan hamba, bahwa Ia datang sebagai hamba untuk mati di kayu salib bagi orang-orang yang dipimpin-Nya (people-oriented), sedangkan kepemimpinan yang manusia lakukan hanyalah berfokuskan pada keuntungan diri sendiri (self-oriented). ${ }^{24}$

Menurut Katarina dan Siswanto, menjelaskan bahwa dalam kepemimpinan Yesus, terdapat setidaknya dua hal yang menjadi bentuk manajemen Yesus dalam

\footnotetext{
${ }^{21}$ Enny Irawati, "Keteladanan Kepemimpinan Yesus serta Implikasi terhadap Kepemimpinan Gereja pada Masa Kini," 172.

${ }^{22}$ Simanjuntak, "Pentingnya Memahami Kepemimpinan menurut Lukas 22:26."

${ }^{23}$ Yahya Wijaya, "Kepemimpinan Yesus sebagai Acuan bagi Kepemimpinan Gereja Masa Kini", 137.

${ }^{24}$ Simanjuntak, "Implementasi Kepemimpinan Yesus Kristus menurut Yohanes 13", 61.
}

memimpin, yaitu pertama, mendelegasikan tugas, di mana Yesus memberikan wewenang atau kekuasaan serta tanggung jawab kepada kedua belas murid-murid-Nya. Kedua, mengevaluasi para murid, di mana Yesus menyediakan waktu secara khusus untuk mendengar dan mengevaluasi para murid (Mrk. 10:30-32; Luk. 9:10-11). ${ }^{25}$

Adapun Simanjuntak mengungkapkan adanya beberapa cara Yesus memimpin, yaitu sebagai berikut: (1) melayani sebagai seorang hamba; (2) menjadi teladan baik dalam hal berdoa, kasih, bahkan pelayanan; (3) menjadi gembala yang mengenal, menjaga, melindungi, menuntun, membimbing, memperhatikan serta memelihara domba-domba-Nya. ${ }^{26}$

\section{Kehidupan Pemuridan}

Hull berpendapat bahwa istilah Pemuridan dalam bahasa Yunani adalah matheteusate yang pengertiannya adalah mencetak seseorang menjadi murid. ${ }^{27}$ Pemuridan adalah suatu proses yang akan menjadikan seorang Kristen memiliki sebuah kedewasaan rohani. Menurut Edmund Chan, seperti yang dikutip oleh Gunawan, menuturkan bahwa pemuridan adalah sebuah proses yang dapat menuntun seorang Kristen ke dalam suatu hubungan yang pulih dengan Tuhan, dengan tujuan akhir yang hendak dicapai adalah suatu kedewasaan rohani yang penuh di dalam Kristus, yang mana hal tersebut dicapai melalui proses pertumbuhan

\footnotetext{
${ }^{25}$ Katarina dan Siswanto, "Keteladanan Kepemimpinan Yesus dan Implikasinya bagi Kepemimpinan Gereja Pada Masa Kini”, 95.

${ }^{26}$ Simanjuntak, "Implementasi Kepemimpinan Yesus Kristus menurut Yohanes $13 ", 65$.

${ }^{27}$ Kezia Yemima, "Strategi Pemuridan Mahasiswa Sekolah Tinggi Teologi Era New Normal Pandemi Covid-19" 2, no. 2 (September 2020): 71.
} 
iman yang didapat melalui pemuridan yang intens, dengan harapan mereka yang dimuridkan mampu memultiplikasikan proses/siklus yang sama kepada orang lain. ${ }^{28}$ Seorang Kristen yang telah dewasa rohani pasti akan mampu berdampak bagi orang lain serta memberi pengaruh kepada orang lain dengan kerinduan agar mereka yang belum mengenal Kristus juga dapat mengalami pemulihan dalam hubungannya dengan Allah melalui Yesus Kristus. Oleh sebab itu, orang Kristen yang sudah menjadi seorang dewasa rohani tentunya akan rindu untuk bermultiplikasi dengan cara memuridkan orang lain.

Dalam sebuah proses pemuridan, tentunya diperlukan suatu komitmen antara kedua belah pihak, yaitu antara pihak yang akan memuridkan dengan pihak yang akan dimuridkan. Di dalam proses tersebut, tentunya harus ada sebuah ikatan relasi antara kedua belah pihak agar proses pemuridan dapat terlaksana dengan baik sehingga dapat menghasilkan sebuah kedewasaan rohani sebagai tujuan utama dari pemuridan. Menurut Greg Ogden dikutip oleh Sitepu, menuturkan bahwa pemuridan berbicara tentang suatu relasi dengan sebuah tujuan di mana seorang pemurid harus berjalan bersama-sama dengan murid-muridnya dengan tujuan agar terciptanya sebuah prinsip "saling", yang meliputi saling mendukung, mendorong dan melengkapi satu sama lain untuk bertumbuh menuju kedewasaan rohani di dalam Yesus Kristus. ${ }^{29}$

Matius 28:19-20 adalah dasar ayat yang bagi pemuridan, di mana ayat tersebut

\footnotetext{
${ }^{28}$ Agung Gunawan, "Pemuridan dan Kedewasaan Rohani," Jurnal Sola Gratia 5, no. 1 (Februari 7, 2020): 6.

${ }^{29}$ Nathanail Sitepu, "Urgensi Menemukan Model Pemuridan Sesuai Tipe
}

dikenal dengan Amanat Agung Tuhan Yesus yang diberikan kepada setiap orang percaya. Menurut Subekti dan Pujiwati, Amanat Agung Tuhan Yesus bersifat mandatarisestafetis yang diungkapkan melalui empat kata kerja imperatif, yaitu: (1) pergilah; (2) jadikanlah; (3) baptislah; dan (4) ajarlah. Pemuridan adalah hal yang memuat keempat kata kerja tersebut (yaitu menjadikan murid). ${ }^{30}$

Dalam Matius 9:35-38, kita dapat melihat adanya suatu kalimat yang cukup populer, yaitu "tuaian memang banyak, tetapi pekerja sedikit". Frase tersebut memperlihatkan bahwa tidak banyak orang yang menyadari urgensi pemuridan. Namun di sisi lain, Yesus terus memperlihatkan serta mengajarkan pola pemuridan ini dengan tujuan agar murid-murid-Nya dapat melakukan hal yang sama kepada orang lain (dimuridkan untuk memuridkan). ${ }^{31}$

\section{Contoh Pemuridan dalam Alkitab}

Dalam pembahasan mengenai pemuridan, kita bisa mengambil contoh konkret di dalam Alkitab. Dalam Perjanjian Lama mencatat satu tokoh yang tepat untuk membahas tentang pemuridan ini, yaitu Elia. Pada zamannya, Elia merupakan seorang nabi bangsa Israel yang dipilih dan dipakai Allah untuk melaksanakan kehendak-Nya. Nabi sendiri adalah orang yang secara sengaja dipilih Tuhan untuk menjadi perantara antara Tuhan dengan manusia, khususnya pada saat itu menjadi perantara antara Tuhan dengan bangsa Israel. Dalam pelayanannya, Elia dipakai Tuhan secara luar biasa, banyak hal-hal yang ajaib dilakukan

\footnotetext{
Spiritualitas Jemaat," Jurnal Harvester 5, no. 2 (Desember 17, 2020): 3-4.

${ }^{30}$ Tri Subekti dan Pujiwati, "Pemuridan Misioner dalam Menyiapkan Perluasan Gereja Lokal," Epigraphe 3, no. 2 (2019): 158.

31 lbid.
} 
oleh Elia. Bahkan lewat pelayanan Elia, bangsa Israel pernah mengalami kebangunan rohani yang besar. Elia tidak hanya sukses dalam pelayanannya sebagai nabi saja, melainkan ia juga sukses menjadi seorang pemurid/mentor. Ia berhasil memuridkan Elisa yang pada akhirnya juga menjadi nabi yang dipakai Tuhan secara lebih luar biasa, bahkan melebihi Elia yang merupakan sang pemuridnya/mentor. Hal ini tidak terlepas dari pemuridan yang dikerjakan oleh Elia. ${ }^{32}$

Adapun hal-hal yang dilakukan Elia dalam pemuridannya terhadap Elisa, yaitu pertama, Elia memberikan motivasi. Sebuah motivasi dari seorang pemurid kepada murid/mentee merupakan salah satu faktor penting dalam pemuridan, karena motivasi dapat mendorong murid/mentee dalam melaksanakan setiap tugas yang diberikan. Apabila kita melihat di dalam Alkitab mengenai kisah Elia dan Elisa memang tidak dijelaskan secara eksplisit mengenai Elia memberikan motivasi kepada Elisa. Soeliasih berkata bahwa Elia sudah menjadi motivasi bagi Elisa. hal ini terlihat dari permohonan Elisa yang menginginkan dua bagian dari roh Elia, dari sini kita bisa menyimpulkan bahwa Elisa ingin menjadi sama seperti Elia. ${ }^{33}$

Lebih spesifik lagi, kita dapat melihat contoh bagaimana Yesus melakukan pemuridan, terkhusus kepada Simon (Petrus), Yuliati dan Yemima menjelaskan bahwa terdapat empat langkahlangkah pemuridan yang dilakukan oleh Yesus, yaitu pertama, penerimaan, di mana

\begin{tabular}{l}
\hline $\begin{array}{c}\text { 32Soeliasih Soeliasih, } \\
\text { Prinsip Pemuridan Elia dalam Pendidikan }\end{array}$ \\
Agama Kristen," Jurnal Teologi Berita Hidup 2, \\
no. 1 (September 30, 2019): 7. \\
33lbid. \\
34Yuliati Yuliati dan Kezia Yemima, \\
"Model Pemuridan Konseling bagi Alumnus
\end{tabular}

Yesus menerima murid-murid-Nya apa pun keadaan mereka, bahkan dalam kasus Simon, Ia memberikan penerimaan saat menanggapi ungkapan penyesalan dosa Simon (Luk. 5:8,10). Kedua, penemanan, di mana Yesus melakukan pendampingan dan memberikan arahan kepada Simon mengenai apa yang harus ia lakukan, yaitu dalam hal menebar jala. Penemanan yang Yesus lakukan kepada Simon menjadi solusi atas kekecewaan dan keputusasaan Simon sebab ia tidak mendapatkan hasil apa-apa setelah semalaman menjala ikan. Ketiga, pengutusan, di mana Yesus memberikan tugas kepada Simon yang semula merupakan penjala ikan, kemudian diubahkan dan dijadikan sebagai penjala manusia, dan hal itu diresponi dengan baik oleh Simon. Sejak saat itulah ia juga mengemban tugas untuk memuridkan orang lain, sama seperti apa yang telah Yesus lakukan kepadanya. ${ }^{34}$

\section{Implementasi Prinsip Dasar Seorang Pemurid yang Berkualitas}

Berdasarkan teori aspek kepemimpinan Yesus yang dipaparkan oleh Wijaya seperti yang telah diungkapkan diatas, penulis menyimpulkan adanya prinsip-prinsip dasar yang dapat diimplementasikan oleh seorang pemurid yang berkualitas dalam pemuridan berdasarkan aspek kepemimpinan Yesus tersebut, yaitu yang pertama, pemuridan dalam gereja masa kini haruslah mengacu kepada Kerajaan Allah, di mana Kristus yang menjadi pusat dalam pemuridan. ${ }^{35}$ Kedua, pemuridan haruslah berisikan bagaimana

\footnotetext{
Perguruan Tinggi Lulusan Baru (Fresh Graduate) yang Mengingkari Panggilan Pelayanan" Jurnal Gamaliel 1, no.1 (Februari 26, 2019): 26-40.

${ }^{35}$ Yahya Wijaya, "Kepemimpinan Yesus sebagai Acuan bagi Kepemimpinan Gereja Masa Kini”, 137.
}

52 | Jurnal Excelsis Deo: Jurnal Teologi, Misiologi dan Pendidikan 
seorang pemurid dapat memperkenalkan Allah sebagai Bapa yang menyayangi anakanak-Nya, sebagaimana Yesus juga memperkenalkan Allah yang bukan hanya sebagai Raja saja, melainkan juga sebagai Bapa, agar terbangun hubungan kekeluargaan antara manusia dengan Allah. ${ }^{36}$ Dan yang ketiga, seorang pemurid/mentor haruslah memimpin murid/menteenya atas dasar hati yang dipenuhi dan digerakkan oleh belas kasihan, sebagaimana Yesus yang memimpin dengan motivasi hati yang penuh dengan belas kasihan, bukan karena nafsu kekuasaan, haus penghormatan, atau kenikmatan fasilitas. ${ }^{37}$ Ketiga hal tersebut adalah prinsip-prinsip dasar yang harus dimiliki oleh seorang pemurid agar pemuridan yang ia jalankan dapat menjadi efektif dan berkenan di hadapan Tuhan. Hal inilah yang perlu ditanamkan oleh setiap gereja kepada setiap pemurid-pemurid/mentor-mentor demi terlahirnya kelompok-kelompok pemuridan yang berkualitas, yang berpusatkan pada Injil.

\section{Tanggung Jawab Seorang Pemurid Yang Berkualitas}

Berdasarkan teori manajemen kepemimpinan Yesus yang dipaparkan oleh Katarina dan Siswanto seperti yang telah diungkapkan di atas, penulis menyimpulkan adanya dua hal yang menjadi tugas, kewajiban, bahkan tanggung jawab seorang pemurid yang berkualitas, yaitu yang pertama, mendelegasikan tugas, di mana seorang pemurid haruslah dapat memberikan wewenang atau kekuasaan serta tanggung jawab kepada murid/mentee-

\footnotetext{
${ }^{36} \mid$ bid., 138
}

${ }^{37}$ Ibid., 141. nya, sebagaimana Yesus mendelegasikan tugas kepada kedua belas murid-murid-Nya. Dalam hal pendelegasian tugas ini, menurut Edgar Walz (2004), seperti yang dikutip oleh Katarina dan Siswanto, menyebutkan adanya tiga unsur di dalam pendelegasian tugas ini, yaitu penyerahan tugas, pemberian wewenang dan penciptaan kewajiban, yang dilakukan dengan menaruh kepercayaan yang penuh kepada penerima delegasi. Lebih lanjut lagi, Katarina dan Siswanto mengutip Soekahar (1988) mengatakan bahwa pendelegasian tugas ini merupakan salah satu cara untuk mempersiapkan para pemimpin rohani, sebab kepemimpinan rohani yang baik tidak akan dapat tercipta tanpa adanya persiapan dalam waktu yang cukup lama. ${ }^{38}$ Kedua, mengevaluasi murid, di mana seorang pemurid/mentor seyogyanya dengan secara rutin mengadakan evaluasi terhadap murid/mentee-nya, sebagai bentuk refleksi diri dalam proses perjalanan menuju keserupaan dengan Kristus, sebagaimana Yesus juga memberikan waktunya secara khusus untuk mendengar dan mengevaluasi para murid-Nya. ${ }^{39}$ Kedua hal inilah yang menjadi tugas dan tanggung jawab setiap pemurid/mentor, di mana kedua hal ini adalah hal yang sangat penting dan perlu untuk dipraktekkan dalam pemuridan, sebab dengan cara inilah eksistensi pemuridan dalam sebuah gereja akan tetap berlanjut dari generasi ke generasi. Dengan kata lain, adalah tanggung jawab seorang pemurid untuk melahirkan murid-murid yang berkualitas, yang akan mampu dan siap diutus untuk menghasilkan murid-murid bahkan pemurid-pemurid lainnya, sampai seluruh bangsa mengenal Yesus Sang Raja,

\footnotetext{
${ }^{38}$ Katarina dan Siswanto, "Keteladanan Kepemimpinan Yesus dan Implikasinya bagi Kepemimpinan Gereja Pada Masa Kini”, 93. 39 Ibid., 93-94.
} 
dan menjadikan mereka sebagai muridmurid-Nya yang sejati.

\section{Sikap Seorang Pemurid Yang Berkualitas}

Berdasarkan cara kepemimpinan Yesus yang dipaparkan oleh Simanjuntak, maka penulis menyimpulkan bahwa ada beberapa cara kepemimpinan yang harus menjadi bagian dalam kehidupan seorang pemurid, yaitu pertama, melayani sebagai seorang hamba. Yesus pernah berkata, "dan barangsiapa ingin menjadi yang terkemuka di antara kamu, hendaklah ia menjadi hamba untuk semuanya." (Mrk. 10:44). Dalam bahasa Yunani istilah "hamba" yang digunakan di ayat ini adalah doulos, sedangkan dalam bahasa Inggris adalah $a$ slave dan bondman. Dalam bahasa Indonesia hamba bisa disebut juga dengan budak. Istilah budak sendiri dapat diartikan dengan seseorang yang tidak mempunyai hak atas dirinya sendiri dan seorang budak memiliki kedudukan yang sangat rendah. Purwanto menjelaskan bahwa, Yesus melalui ayat ini ingin menyampaikan bahwa bila ingin menjadi yang terkemuka atau menjadi pemimpin, maka orang tersebut harus mau menjadi pelayan bagi setiap orang yang dipimpin tersebut. ${ }^{40}$ Sikap kepemimpinan Yesus yang disampaikannya itu bisa disebut juga dengan sikap kepemimpinan melayani, artinya dimana yang menjadi fokus dan tujuan dari seorang pemurid bukanlah untuk mendapatkan kedudukan dan tempat yang tinggi, melainkan seorang pemurid/mentor seharusnya mempunyai kerelaan dan keinginan untuk melayani orang-orang yang

\footnotetext{
${ }^{40}$ Agus Purwanto, "Kepemimpinan Yesus Kristus sebagai Model Kepemimpinan Kristen" 1, no. 2 (2020): 131-146.

41 lbid., 137.

${ }^{42}$ Djone Georges Nicolas dan Tirza Manaroinsong, "Krisis Keteladanan
}

berada di bawah kepemimpinannya tersebut. $^{41}$ Kedua, menjadi teladan baik dalam hal berdoa, kasih bahkan pelayanan. Keteladanan merupakan salah satu hal yang sangat melekat dalam kepemimpinan. Mengapa dapat demikian? Menurut Nicolas dan Manaroinsong, hal itu disebabkan karena kepemimpinan secara umum pun sangat menuntut keteladan yang terpancar dari seorang pemimpin, terlebih lagi kepemimpinan Kristen. ${ }^{42}$ Dalam hal ini mengenai konteks pemuridan, maka juga sangat dituntut keteladan dari seorang pemurid tersebut. Ketiga, pemurid haruslah menjadi gembala yang mengenal, menjaga, melindungi, menuntun, membimbing, memperhatikan serta memelihara murid/mentee-nya. Mengenal: berbicara tentang bagaimana seorang pemurid harus mengenali berbagai aspek kehidupan dari yang dimuridkan, baik dalam hal pertumbuhan kerohanian, maupun hal-hal duniawi yang berkaitan dengan kehidupan murid/mentee-nya. Menjaga: berbicara tentang bagaimana seorang pemurid harus berjaga-jaga atas jiwa orang yang dimuridkan dengan hati yang gembira, bukan dengan keluh kesah (band. Ibr. 13:7). Melindungi: berbicara tentang bagaimana seorang pemurid harus melindungi orang yang dimuridkan dari berbagai ajaran sesat, pergaulan buruk dan lain semacamnya agar mereka tidak menyimpang dari kebenaran firman Tuhan. Menuntun dan membimbing: berbicara tentang bagaimana seorang pemurid memiliki kewajiban untuk menuntun dan membimbing orang yang dimuridkan kepada kebenaran firman Tuhan

Kepemimpinan Gereja: Fondasi Gembala sebagai Pemimpin Gereja berdasarkan 1 Petrus 5:2-4," Syntax Idea 3, no. 2 (Februari 20, 2021): $1-8$.

54 | Jurnal Excelsis Deo: Jurnal Teologi, Misiologi dan Pendidikan 
untuk menuju keserupaan dengan Kristus. Memperhatikan: berbicara tentang bagaimana seorang pemurid harus memperhatikan setiap apa yang menjadi kebutuhan orang yang dimuridkan, di mana dibutuhkan hati yang penuh dengan kepekaan untuk melihat dan memahami apa yang menjadi kebutuhannya. Memelihara: berbicara mengenai bagaimana seorang pemurid harus memastikan agar kerohanian orang yang dimuridkan tetap terpelihara dengan baik bahkan mengalami pertumbuhan yang subur dalam hal kerohanian, seperti halnya seseorang memelihara sebuah pohon supaya pohon tersebut dapat berakar kuat, bertumbuh, bahkan berbuah lebat.

\section{Pola Pemuridan Yang Berkualitas}

Berdasarkan pola pemuridan yang dipaparkan oleh Yuliati dan Yelmima pada teori yang telah dibahas sebelumnya, maka penulis menyimpulkan adanya pola pemuridan yang harus dijalankan oleh seorang pemurid, yaitu penerimaan, penemanan, dan pengutusan. Penerimaan: berbicara tentang bagaimana seorang pemurid/mentor harus menerima murid/mentee-nya apa adanya, terlebih lagi di saat seorang murid/mentee sedang mengakui keberdosaannya, sama seperti Yesus yang meresponi Simon dengan penerimaan saat Simon mengakui keberdosaannya. Karena melalui penerimaan inilah kasih Bapa di Sorga menjadi nyata sempurna dirasakan oleh orang lain. Penemenan: berbicara tentang bagaimana seorang pemurid mau "berjalan dan berjuang bersama-sama" dengan murid/mentee-nya untuk mencapai keserupaan dengan Kristus. Tentunya hal itu hanya akan dapat dicapai jika seorang pemurid dengan rutin mengajak murid/mentee-nya untuk terus mendalami firman Tuhan. Pengutusan: berbicara tentang bagaimana seorang pemurid mengimpartasikan misi pemuridan tersebut agar sang murid/mentee dapat kembali memuridkan orang lain, sama seperti ia telah dimuridkan oleh mentornya. Impartasi mengenai beban pemuridan adalah hal yang wajib dilakukan oleh seorang pemurid, agar eksistensi pemuridan terus berjalan dari generasi ke generasi dan misi Amanat Agung Tuhan Yesus terpenuhi.

\section{KESIMPULAN}

Bertolak dari begitu pentingnya kepemimpinan dalam segala bidang kehidupan, salah satunya dalam kehidupan bergereja, secara khusus dalam kehidupan pemuridan, maka sudah semestinya bagi gereja untuk mempersiapkan pemuridpemurid yang berkualitas seperti Kristus yang menjadi standard/teladannya. Demi menjalankan tugas dan panggilan gereja dalam melaksanakan mandat Amanat Agung yang Tuhan Yesus berikan dalam Matius 28:19-20, maka pemuridan adalah jawaban yang tepat untuk menjadi sarana bagi gereja dalam melaksanakan mandat tersebut. Namun demikian, gereja tidak boleh hanya sekadar mengutus tanpa memperlengkapi setiap pemurid yang ada mengenai bagaimana mereka harus memuridkan orang lain. Sudah sepatutnya bagi gereja untuk membekali para pemurid dengan berbagai fasilitas, terutama mengenai aspek kognitif, mengenai bagaimana setiap pemurid dapat memimpin orang lain menuju kepada keserupaan dengan Kristus sebagai murid Kristus yang sejati. Untuk itu, gereja perlu mendorong/mengedukasi para pemurid agar mereka memiliki kualifikasi yang baik dengan berkaca pada kepemimpinan hamba yang Yesus lakukan. Implementasi Gaya 
Kepemimpinan Yesus sebagai role-model dalam kehidupan pemuridan setidaknya mencakup 4 (empat) aspek, yaitu: (1) Prinsip dasar dalam memuridkan, yaitu berpusatkan pada Kristus, memperkenalkan Allah sebagai Bapa, dan memimpin dengan hati yang berbelas kasih; (2) Tanggung jawab seorang pemurid, yaitu mendelegasikan tugas serta mengevaluasi murid; dan juga (3) bagaimana seorang pemurid harus bersikap, yaitu melayani dengan hati hamba, menjadi teladan dalam segala hal, dan menjadi gembala yang peduli dengan domba-dombanya; (4) Pola pemuridan, yaitu penerimaan, penemanan dan pengutusan. Keempat aspek tersebutlah yang kita temukan dalam Pribadi Yesus sewaktu Ia hidup di dunia ini, dan hal tersebut adalah sebuah sejarah yang wajib kita pahami dan kita implementasikan dalam kehidupan kita sekarang ini, termasuk salah satunya dalam kehidupan pemuridan.

\section{DAFTAR PUSTAKA}

Darmawan, I Putu Ayub. "Jadikanlah Murid: Tugas Pemuridan Gereja menurut Matius 28:18-20.” Jurnal Evangelikal 3, no. 2 (July 31, 2019): 144-153.

Gunawan, Agung. "Pemuridan dan Kedewasaan Rohani." Jurnal Sola Gratia 5, no. 1 (February 7, 2020): $1-17$.

Irawati, Enny. "Keteladanan Kepemimpinan Yesus serta Implikasi terhadap Kepemimpinan Gereja Masa Kini." Jurnal Ilmu Sosial dan Humaniora 10, no.1 (2021): 169-184.

Katarina, K, dan Krido Siswanto. "Keteladanan Kepemimpinan Yesus dan Implikasinya bagi Kepemimpinan Gereja Pada Masa
Kini." Jurnal Evangelikal 2, no. 2 (Juli 31, 2018): 87-98.

Lase, Jason. "Kepemimpinan dan Tantangan Pluralisme Sosial." Jurnal Jaffray 7, no. 1 (2009): 1-15.

Mawikere, Marde Christian Stenly. "Efektivitas, Efisiensi dan Kesehatan Hubungan Organisasi Pelayanan dalam Kepemimpinan Kristen.” Jurnal Evangelikal 2, no. 1 (Februari 23, 2018). https://journal.sttsimpson.ac.id/index. $\mathrm{php/EJTI/article/view/95.}$

Nicolas, Djone Georges dan Tirza Manaroinsong. "Krisis Keteladanan Kepemimpinan Gereja: Fondasi Gembala sebagai Pemimpin Gereja berdasarkan 1 Petrus 5:2-4." Syntax Idea 3, no. 2 (Februari 20, 2021): 1-8. Pasande, Purnama. "Pemimpin dan Kepemimpinan Kristen (Memahami Substansi Kepemimpinan Kristen)", OSF Preprints. 2020.

Purwanto, Agus. "Kepemimpinan Yesus Kristus sebagai Model Kepemimpinan Kristen”. Jurnal Mathetes 1, no. 2 (2020): 131-146.

Sahartian, Santy, dan Samuel Brian Septiadi. "Tugas Pemimpinan Muda Kristen Masa Kini sebagai Gembala menurut 1 Timotius 4." Jurnal Angelion 1, no. 1 (2020): 83-97.

Sanjaya, Yudhy. "Kepemimpinan Kristen: Leader sebagai Kualifikasi Kepemimpinan Nehemia". Preprint. Open Science Framework, August 4, 2020. Accessed May 29, 2021. https://osf.io/vchns.

Simanjuntak, Hotman Parulian. "Implementasi Kepemimpinan Yesus Kristus menurut Yohanes 13:1-20.” Jurnal Shamayim 1, no. 1 (2020): 5877. 
Simanjuntak, Josua Marsorin. "Pentingnya Memahami Kepemimpinan menurut Lukas 22:26." Jurnal Stella 1, no. 1 (2021): 29-44.

Sitepu, Nathanail. "Urgensi Menemukan Model Pemuridan Sesuai Tipe Spiritualitas Jemaat." Jurnal Harvester 5, no. 2 (December 17, 2020): 105-119.

Soeliasih, Soeliasih. "Penerapan Prinsip Pemuridan Elia dalam Pendidikan Agama Kristen." Jurnal Teologi Berita Hidup 2, no. 1 (September 30, 2019): 1-10.

Subekti, Tri dan Pujiwati. "Pemuridan Misioner dalam Menyiapkan Perluasan Gereja Lokal." Jurnal Epigraphe 3, no. 2 (2019): 157-172. Sudibyo, Tenny, dan Areyne Christi. "Implementasi Prinsip Kepemimpinan Rasul Paulus Paulus berdasarkan Surat 1 Timotius 3:1-13

Jurnal Gamaliel 1, no. 1 (Februari 26, 2019): 26-40.
\& 2 Timotius 2:2-6 di Kalangan Cititas Akamedika Sekolah Tinggi Teologi”. Jurnal Excelsior Pendidikan 1, no. 1 (2020): 22-44.

Tomatala, Yakob T. "Leading by Serving: Memimpin dengan Melayani." Voice of Wesley 2, no. 2 (2019): 1-18.

Wijaya, Yahya. "Kepemimpinan Yesus sebagai Acuan bagi Kepemimpinan Gereja Masa Kini." Jurnal Jaffray 16, no. 2 (Juli 24, 2018): 129-144.

Yemima, Kezia. "Strategi Pemuridan Mahasiswa Sekolah Tinggi Teologi Era New Normal Pandemi Covid-19" 2, no. 2 (September 2020): 68-81.

Yuliati, Yuliati dan Kezia Yemima. "Model Pemuridan Konseling bagi Alumnus Perguruan Tinggi Lulusan Baru (Fresh Graduate) yang Mengingkari Panggilan Pelayanan." Jurnal Gamaliel 1, no.1 (2019). 
Jurnal Excelsis Deo: Vol. 5, No. 1 Juni 2021

58 | Jurnal Excelsis Deo: Jurnal Teologi, Misiologi dan Pendidikan 